\title{
OPEN SECTION
}

\section{The meaning of 'Made in Italy' in fashion}

\section{Simona Segre Reinach}

\begin{abstract}
In this paper I set out to account for the transformations and specific features of Italian fashion within a broader scenario created by the globalisation of industry, markets and consumption.

While a retrospective gaze may lead us to interpret Italian fashion as a phenomenon that has simply evolved in time, a closer examination reveals a development made up of continuity, but also of discontinuities. Continuity may be perceived in the production of quality fabrics and artisan competences scattered throughout Italy. The discontinuities highlight different fashion cultures, production and consumption marking the phases of its development.
\end{abstract}

\section{Introduction}

While a retrospective gaze may lead us to interpret Italian fashion as a phenomenon that has simply evolved over time, a closer examination reveals development that is made up of continuity, but also of discontinuities. Continuity is evident in the production of quality fabrics and artisan competencies scattered throughout Italy. The discontinuities are highlighted by varied fashion cultures, production and consumption marking the phases of its development. Presentday Italian fashion lacks the precise profile that it had in the past decades, but 'Italian style' is still recognisable. What exactly Italian style is, however, is not easy to grasp. In this essay, I suggest that understanding the concept of 'Made in Italy' in relation to Italian style requires research into the cultural history of Italian fashion and design, its ambiguities and historical evolution. This essay aims to account for the transformations and specific features of Italian fashion within the broader scenario created by the globalisation of industry, markets and consumption. ${ }^{1}$ The basic ingredients of Italian fashion were defined in 1981 in a special issue of Domus, the celebrated journal of architecture and design, which was devoted to fashion. The Milanese architect and director of Domus,

\footnotetext{
1 Specific anthropological fieldwork to analyse the structure of the fashion industry, and not only its image, makes a valuable contribution to such research.
} 
Alessandro Mendini, was ahead of his time in recognising the relevance of fashion in postwar Italian culture and history. ${ }^{2}$ In that issue of Domus, Italian style was defined as being characterised by:

crystal clear shapes, sharp cuts, precious fabrics, refined finishings showing a bond between craftmanship and industry, a good balance of realism and imagination. (Domus Moda 1981)

This is a good, although florid, definition to start with. But, a theory of Italian fashion is still to be properly arrived at, as the cultural history of Italian fashion has only recently begun to be researched (Colaiacomo 2006; Fortunati and Danese 2005; Lupano and Vaccari 2010; Frisa 2011; Muzzarelli, Frisa and Tonchi 2014). In this essay, I argue that there are two main reasons for this lack of research. The first is the difficulty that Italian scholars have in historicising Italian fashion, so to speak, as if fashion was a 'natural' outcome of the development of the country in which the Renaissance had its origins. This is what I have called elsewhere the naturalisation of taste (Segre Reinach 2010), a sort of essentialism by which the outcome of a precise history of an industry is reduced to a theory of innate talent for fashion, an ethnocentric version of what the sociologist Joanne Entwistle has called tacit aesthetic knowledge (2009). The second one is a 'fixation' on the period of the maximum splendour of Italian fashion, the prêt-à-porter of Milanese design in the late 1970s and 1980s. ${ }^{3}$

\section{'Emancipation from Paris': Fashion and national identity}

It is well known that in the mid-twentieth century in Europe, the United States and also in other non-Western countries with strong colonial links to the West, local industries arose in an attempt to liberate fashion from the cultural dominance of Paris. The production and cultural system of Parisian haute couture and its celebrated couturiers, led to its establishment as a benchmark for any other emergent fashion: for example, fashion designer Claire McCardell thus became the 'American answer' to Dior's New Look, while Shanghai in the 1930s was the 'Paris of the East'. Until the 1950s, many nations or cities alternated between imitation of Parisian models, and the inevitable adaptation of the same to local tastes and culture, along with the occasional aim of becoming independent from Paris. We must, however, stress that it was not a question of a single process of 'freeing themselves' from Paris or, rather, initially stepping up to equality with French fashion. Instead, specific fashions took shape in time. Under the label of 'national fashion', various anthropologies of production and consumption

2 Although Domus was not the first journal to understand the relevance of Italian fashion, it was certainly the first one to focus on the link between fashion design, modernity and industry in Italian prêt-à-porter.

3 As Italian prêt-à-porter of the 1980s (for both for men and women) was the main output of the Italian fashion industry, other sectors, such as 'fast fashion' and 'private label' ready to wear, have been given limited consideration here. 
have developed, relating to the individual histories that each nation, city or town has interwoven with the production of apparel, with the textile industry and the competencies of its craftspeople.

In the 1950s, Italy began to assert its identity in the field of fashion. The process was completed between the 1970s and the 1980s, with the invention of the prêt-à-porter of Italian fashion designers - the so-called stilisti (Steele 2003). Italian fashion is, therefore, one of the first sartorial industries, along with Japanese radical fashion (Kawamura 2004) to 'emancipate from Paris' and transform itself from a simple clothing-textile industry to a cultural industry that is evolving from the secondary sector to the tertiary one. While France maintains its dominance of high fashion and luxury, Italy has made a name for wearable elegance and industrial capacity, England is the symbol of both tradition and innovation ${ }^{4}$ (Breward 2004), Japan expresses 'deconstruction', minimalism and a certain brand of street culture, and the United States has 'invented' casual and sportswear. The process of establishing independence from Paris continues and the contemporary scenario is marked by a multiplicity of fashion cities and nations (Skov 2011), as is shown by the increasingly numerous 'fashion weeks' that take place in the farthest flung 'fashion capitals' including Shanghai, Bombay, Berlin, São Paulo, Jakarta, Sydney, Tel Aviv and Istanbul (Segre Reinach 2011).

The sartorial histories of the countries that have found themselves on the stage of stylistic desirability, once the process of multiplication of the centres has been set off, are particular and idiosyncratic. The 'new players' seek to blend local specialisations and capacities with globalised aesthetics that, not infrequently, clash with stereotyped, conventional ideas. Brazil, for example, seeks to set itself free from the beachwear stereotype, while India tries to shed its image as a source of 'Oriental' products and handwork such as beading. The intensification of outsourcing, moreover, has changed not only the geography of fashion, but also the relationship between 'made in' and national creativity. In some cases, sartorial identities have become more fragile while, in others, such identities have been strengthened, making a greater freedom of expression possible. For countries with a mainly productive tradition, such as Ireland, the loss of the manufacturing aspect has left the country, so to speak, a 'fashion orphan' (Skov 2011). For others, on the contrary, it has been possible to relaunch a postmodern, immaterial identity without having to compensate for a local manufacturing tradition that was never very significant, as in Iceland. Thus, the race towards achieving a recognised and recognisable fashion is also run by countries that, so far, have not known how or been able to express a significant sartorial positioning. Investment made by the Chinese Government to develop the idea of a creative and not only productive China is a case in point in that it has set out to enhance its historical artisan skills throughout the subcontinent by supporting the careers of its young designers (Keane 2013).

4 As in London's diverse traditions of Saville Row tailoring and the swinging 1960s of Carnaby St. 
For the well-known anthropologist and philosopher René Girard (1979), mimetic desire is a sort of universal engine that may be synthesised in this simple, adamantine statement: 'I desire what the other desires'. The triangulation of desire ${ }^{5}$ makes objects a means to draw closer to another person whose charm we feel, not merely the fulfilment of a desire for possession. In this light, the production of a fashion is a complex cultural fact and not only an aspect of the economy of a country. This leads us directly to the fundamental meaning that dress has, in a relational sense, to the dynamics of taste and its manifestations between people and between nations. The capacity to produce fashion - that is, a desirable, commercially successful aesthetic -is linked to a set of conditions that is connected to national cultural identity. Having creative authority means that others wish to wear what a country/culture produces, which poses the question of the dynamics of sartorial style undergoing continuous change. The affirmation of a place and of a culture that may boast a situation of prestige in the arena of global fashion depends on the interlinked ideas, prejudices or reputations that others may form - which is based on many factors, not only on the ability to produce something of aesthetic importance. While the producers of apparel, the commercial firms and companies, are increasingly diversified and transnational, the relation between fashion and national identity is strengthened instead of dispersed. ${ }^{6}$ The outcome is a sort of aesthetic nationalism that has nothing to do with nineteenth-century romantic nationalism, but is more like a sort of potlach; that is, a complex exchange system in which the objects circulating are garments, designers, images and brands that are aimed at strengthening competence and prestige.

Producing, communicating and presenting a 'recognised' fashion thus goes far beyond the original meaning of more or less specialised textile and clothing production. The requisites of a fashion project today include material and commercial aspects and communicational and immaterial ones. Fashion as a tool for communication is also used by governments to promote tourism, to establish international relations, to compete and exchange ideas and projects, as well as a sought-after quality demanded by people to feel desirable and in step with the times. Being able to express and communicate a successful aesthetics beyond the indigenous community is now an important corollary that indirectly signals cultural and economic strength. As the sociologist Diane Crane (2000) explains, this is because, unlike other production and commercial activities, fashion expresses an elaborate culture that is composed of symbols, ideologies and lifestyles on which to draw and favour consensus and exchange. Much more than in the past, fashion has the task to reflect and represent not only social or individual needs, but also diversified possibilities to construct ex novo areas in which the imaginary is creatively set free. Up until the 1980s, fashion

5 That is, according to Girard, an always yielding to what appeals to others.

6 Paradoxically, in our globalised culture, the concept of the fashion nation with its glamourised brands becomes more relevant. 
was not considered as an academic topic or a cultural industry, but simply part of the manufacturing or textile sector-and very often it is only a by-product. As historian Regina Lee Blaszczyk maintains:

In recent decades, fashion history has blossomed into a thriving field, attracting scholars from anthropology, sociology, history, home economics, cultural studies, and fashion design. Building on insights from earlier studies by curators and connoisseurs of dress and costume, a new generation of scholars has situated fashion within broader historical and cultural frameworks. (2008: 8-9)

Identity in fashion has, therefore, become a major issue - not just as an industry, but as a passport for modernity. As French sociologist Frederic Godart (2012) maintains, fashion has become an indispensable reference for all forms of culture and other creative industries. The broadening significance of dress has transformed fashion into a brilliant synthetic indicator that is able to express the importance and symbolic capital of a country.

It is not easy, however, for a country to make its name on the globalised fashion circuit. As artist Adam Geczy puts it:

Fashion and dress are the very best loci by which to understand the various spaces by which the signs of nation, identity and novelty have become transacted, adapted and owned. (2013: 4)

This is a new concept that is applicable to those nations, such as Turkey, Brazil and China, that seek to use fashion to express themselves as relevant contributors to modern cultural industries, or to nations like Japan and its radical fashion of the 1980s, whose fashion has been the subject of theorising since the beginning.

Italy, however, is different, as the next section illustrates. It became a fashion nation well before it became a nation. The long process started in the Renaissance and continued throughout the nineteenth and twentieth centuries, including during the autocratic utopia of Benito Mussolini, beginning in 1936 (see Paulicelli 2004; Lupano and Vaccari 2010) up to the rise of the Milanese fashion designers in the late 1970s.

\section{Italian fashion in the making: The rise of prêt-à-porter}

For historical and anthropological reasons, Italian fashion has often been marked by strong regional and local connotations that are expressed not only in diversified producers - such as Como silks, wools from Biella, Prato carded wool, embroidery from Assisi, Brenta shoes - but also in the competition between cities, such as Turin, Florence, Rome and Milan, for fashion dominance. It is a system that is shaped by 'embedded flexible networks' (Godart 2012: 134). 
In the 1930s, during Fascism - when a true Italian fashion did not yet exist and the tailoring and dressmaking ateliers looked to Paris for women's fashion, London for men's fashion, and the textile industry was still in its cradle-the fascist regime nominated Turin as the capital of design and aimed to invent and impose the fashion of Turin on Italy and abroad as a fashion of purely Italian inspiration and production.

Despite the efforts of the regime, the success of the campaign was modest. With the exception of Ferragamo and Gucci in accessories, recognition of Italian fashion as a competitor to Paris was achieved only after the Second World War, in Florence in 1951 (Caratozzolo 2006). The characteristics with which Italian fashion made its name, compared with French fashion, were the wearability of its garments, quality of fabrics and of details in general, and an overall allure that was more modern and casual and better suited to the times. The styles were also more easily reproducible for sale in American department stores. Florentine fashion was thus highly successful, thanks to the favour granted it by the United States. From the beginning, however, parochialism inhibited the fashion industry from developing and organising as a united sector. Positioning shifted between Florence, Rome-the home of many high fashion tailoring and dressmaking establishments-Naples and Milan, both of which also pursued the status of first in Italian fashion. Ultimately, Rome became the home of high fashion and Florence of ready-to-wear. At this point, Florence should have developed a closer relationship with the textile industry to facilitate greater expansion in the 1960s, however, while it appeared modern in the 1950s with the designs of Emilio Pucci and Roberto Capucci and the novelty of the fashion boutique, after almost 20 years Florence was unable to meet the public's changed expectations, the region's capacity and the very needs of the fashion designers themselves. Florence did not have the necessary infrastructure to support the early experiments in fashion design and production on an industrial scale. It was not sufficiently connected with the textile industry or the service sector, including press, photography, PR agencies, and these elements were a crucial factor for the transformation of fashion from a product for the wealthy, which it still was, into a mass language, as it was getting ready to become. The fashion designers complained that Florentine organisations, too antiquated in formula, did not enable them to fully display their skills. Another place had to be found (Mulassano 1979). It was at that point that a series of factors brought Milan to attention of the nascent system of Italian fashion. Although until then it had not played a recognised role in fashion (in 1906 it hosted the first exhibition to develop Italian fashion and, in 1948, the Centro italiano della moda was opened by Filippo Marinotti, the director of the synthetic textile company Snia Viscosa), it was for many reasons the 'natural' place in which to develop the idea of prêt-à-porter, which was then emerging, as well as being the driving engine of the first economic boom in Italy (Foot 2001; Segre Reinach 2006; Volonté 2012). 
When in 1972-20 years after the historic first fashion show in Florence organised by Giovanbattista Giorgini in 1951-some fashion designersincluding Walter Albini, who is to be considered one of the precursors of the stilista figure-decided to leave the Florentine catwalks to show in Milan, the Lombard capital was already the home to trade derived from the fashion sector. Milanovendemoda, the collective of agents and commercial representatives in the clothing industry had been active since 1969, with the aim of enhancing relationships with the many buyers who were already present in Milan. The city was also sensitive to the youthful anti-fashion revolutions that were occurring across Europe and the United States, in particular what was happening in London and San Francisco. Inspired by the Biba store in London, Elio Fiorucci's store was a meeting point for young people wishing to distance themselves from middle-class, conservative apparel, recognising the growing importance of the communicative aspect of fashion.

The move from Florence to Milan as a ready-to-wear centre documents a change in perspective of Italian fashion, from a product of art and culture, as American observers had interpreted and promoted it, to a practice of modernity. At the international level, the rise of Milan was the start of the transformation of fashion as the expression of class and good taste to a popular language. Geographically also, Milan was ideal as a fashion centre, situated as it is at the centre of the industrial districts that made an integrated design, production and distribution system possible. The textile, clothing and leatherwear sectors have developed harmoniously in Italy, despite their diversity, unlike in other countries where the development of one sector has not necessarily corresponded to the presence or growth of another. The city also acted as a district of post-production and communication activities. The presence and concentration of commercial television companies, fashion magazines, advertising and PR agencies marked Milan as a Lombard district of media production. The city, therefore, became the meeting point between industry and the service-producing sector. 


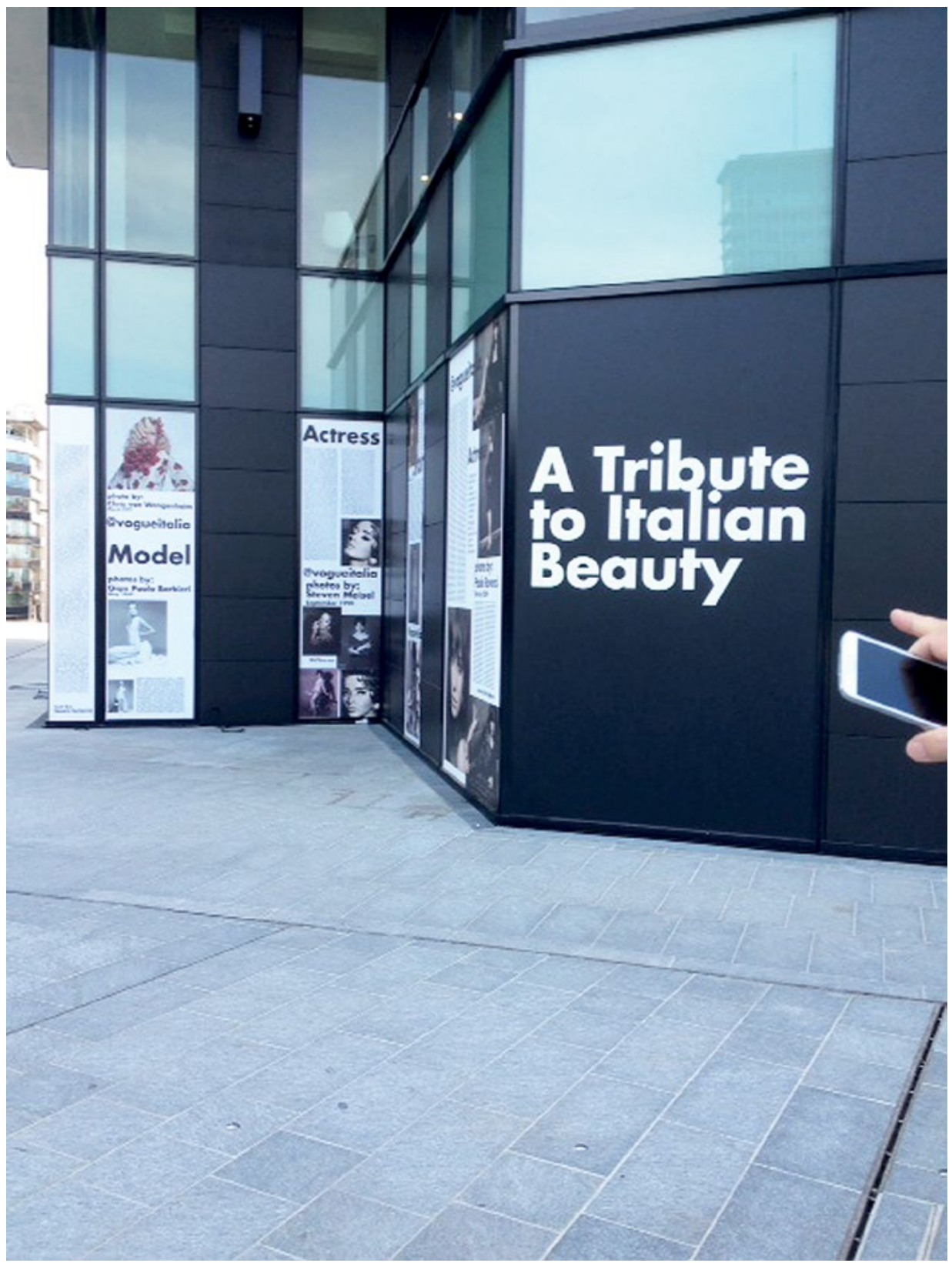

Figure 1. Milan: The Porta Nuova Project

Photo: Simona Segre Reinach, 2014

The fashion industry in Milan grew rapidly between 1970 and 1978 and was widely acknowledged nationally for its prestige. Despite the troubled years of political terrorism (1969-81) and the oil and industrial crisis in the early 1970s, Milanese fashion gave new strength to the Italian economy. After being the centre of the 
economic boom of the 1960s, Lombardy also found in Milanese fashion a means to overcome the crisis in heavy industry, with a swift reconversion (Foot 2001). In the years between 1974 and 1978, Milan and its industry were protagonists in establishing the basis for the next decade's economic boom in Italy. In this period, leading textile associations were formed and strengthened, including IdeaComo, the union of silk textiles (1974), and Federtessile, which grouped together 10 textile associations (1975). Designers such as Armani, Versace, Coveri and Krizia started to converge on Milan. The Italian stilisti were, and still are, predominantly business people in their own right or in partnership with an entrepreneurial figure who assists in handling complex international markets. Franco Mattioli and Gianfranco Ferré, Sergio Galeotti and Giorgi Armani, Aldo Pinto and Krizia, Rosita and Ottavio Missoni, Massimo and Alberta Ferretti, Tiziano Giusti and Franco Moschino, Domenico Dolce and Stefano Gabbana are a few examples. The investment of the Industriali dell'Abbigiamento e della Maglieria associations in Modit, the entity that oversees Italian catwalk shows, clearly established industry as having a role in the prêt-à-porter project. In the mid-1980s a new generation of designers emerged, including Dolce \& Gabbana, Romeo Gigli and Miuccia Prada.

The 1990s saw the opening of Carla Sozzani's concept store, 10 corso Como. Avant-garde in its choice of location near Milan's Garibaldi Station, which was still a working class area, and distant from the downtown Quadrilatero fashion area, this store marked the beginning of fashion's spread into peripheral districts in the city, such as Porta Genova, the Bovisa and Porta Vittoria. Following this, the fashion designers redeveloped the vacant, former industrial areas outside the city centre.

In the 1990s, however, prêt-à-porter underwent a crisis. There were various causes. The dominance of branding and the rise of luxury conglomerates damaged the 'democratic' origins that characterised the model and had been one of the reasons for its success. The formation of large luxury groups that were designed to compete in an internationalised market modified the manufacturing model of Italian fashion. Relocation and the rise of new competitors, above all in China, created difficulties for small companies that were unable to represent difference or which did not have a product with high added value. The weakness in the marketing strategies of the small firms, the lack of state support and the emergence and strengthening of the luxury multinationals made the Milanbased fashion system vulnerable to increasingly strong competition. Also, from the design point of view, consumer tastes began to change. Italian style par excellence-that of a relaxed, accessible elegance-came to be out of sync with the growing appreciation of independent creativity that marked English or Belgian production and was less and less the hallmark of Italian design. 
The production and cultural model of Milanese prêt-à-porter is no longer the dominant system in fashion in Italy and elsewhere. New production and consumption models modified the shape of the Italian and world fashion industry.

\section{Beyond the stilisti: A new fashionscape}

The figure of the fashion designer has changed. The new generation of designers come from a different background and fashion creativity has become very much a matter of global exchange, as is its production, which is typical of the structure of most industry nowadays. This is a historical evolution of what Godart calls 'the principle of personalisation' (2012: 144) by which the mythology of the designer as isolated creative genius is fostered. It is, however, difficult for emerging designers to establish themselves in the new context, which is in some ways blocked by the presence of the old guard. As sociologist Giampaolo Proni states, the 'Made in Italy' campaign had three main features:

The designer, who combines the roles of creator and manager in one person; the production system mostly allocated in industrial districts, with an upstream and downstream production chain; ready to wear as the production protocol. (2011: 64)

Proni is describing the 1980s model of prêt-à-porter, which had been replaced by low-cost fashion products that are issued continuously as 'fast fashion' and by artisan-produced, postmodern and technically sophisticated luxury. Fast fashion has modified the traditional seasonal divisions of fashion with the presentation of novelties. Its strong point is speed, attention to new consumers and prices that are matched to the latest trends. In the model of the multinationals Zara and $\mathrm{H} \& \mathrm{M}$, but in a sui generis variation, a significant part of new Italian fashion is made up by producers of ready-to-wear fashion brands, such as Patrizia Pepe, Pinko, Celyn B, Liu-Jo, Carpisa and Fracomina. This phenomenon has a cultural and economic impact in that it represents an evolution of the Milan-based model to one emanating from the ready-to-wear fashion centres of Bologna and Naples. A new 'atlas of Italian fashion' is taking shape, in both geographic and cultural terms, which is more composite than the one that existed in the 1980s (Frisa 2011). Large multinational or Italian-owned manufacturers of luxury goods, such as Zegna, Loro Piana and Prada, are now operating alongside fast fashion brands; demi-couture brands such as Albino and Sara Lanzi, which are characterised by experimentation, artisan workmanship and technology; and sportswear and casual brands with Anglicised names (Sweet Years, A-Style, Guru). In the complex new Italian fashionscape, it is clear that brands of all kinds are more relevant than fashion designers themselves. 
Fashion is still an important industry for Italy and its economic contribution to employment is rightly acknowledged. The economic aspect of fashion, however, is only a part of the phenomenon. At the crossroad between art, commerce and industry, modern fashion is also and above all a cultural phenomenon with historical and anthropological components that merit analysis. Entrepreneurs are driving the development of a new model that has the potential to maintain the international precedence of Italian fashion and luxury, and thus competing with the French multinationals. A 2012 alliance between Zegna, Loro Piana and Marzotto is an example of the new trend for disparate companies to become joint shareholders in companies from associated industries (in this case, Pettinatura di Verrone, a company that finishes wool and cashmere), thus inaugurating a partnership between large companies in the sector with the aim of keeping alive the service activities of transformation, which is one of the strong points of Italian fashion. The market is changing and this makes it possible to knock down the historic barriers preventing Italian entrepreneurs from joining forces and increasing market share. On the other hand, the sale of Italian brands to foreign groups is also occurring. Loro Piana, for example, was acquired by LVMH (Moet Hennesy Louis Vuitton) in July 2013, and there has been much commentary on the fact that luxury brands are losing their Italian roots. There are two opposite interpretations of this process. For some analysts this is seen as the Italian fashion industry's loss of influence. For others, however, this process reinforces Italian identity by injecting financial capital into the domestic industry to allow it to operate on a global scale.

\section{Towards an anthropology of Italian fashion}

The history of Italian fashion is exemplary in the industry's ability to enhance its special features and its constant adaptation to sociocultural humus. If, once the current global recession is over (which data suggests might happen soon (Bottoni 2013)), 'Made in Italy', in its various meanings, succeeds in overcoming the challenge of internationalisation and globalisation of the markets, it is no less important to pinpoint its identity, features and the new forms of production and consumption that surround it. In other words, to prepare for the future of Italian fashion, it is necessary to understand why Milan took its place alongside Paris as a fashion capital.

Today, Italian fashion - which in many cases wishes to be distinguished from a 'Made in Italy' with which it no longer completely identifies - signifies a capacity for experimentation and increasingly transnational creativity. The Italian fashion of today, therefore, is reinventing itself again. It is not yet clear the direction in which it is heading and there remain many questions to be answered including, for example, how producers can fuse the commercial need for mass production with the demand for quality. Equally, how can they produce aesthetically interesting productions at moderate prices so as to successfully challenge the 
dominance of international fast fashion? How can production on an industrial scale be sustained and how will commercial growth via investment impact on family-managed firms? It is the market that will determine the answers to these questions.

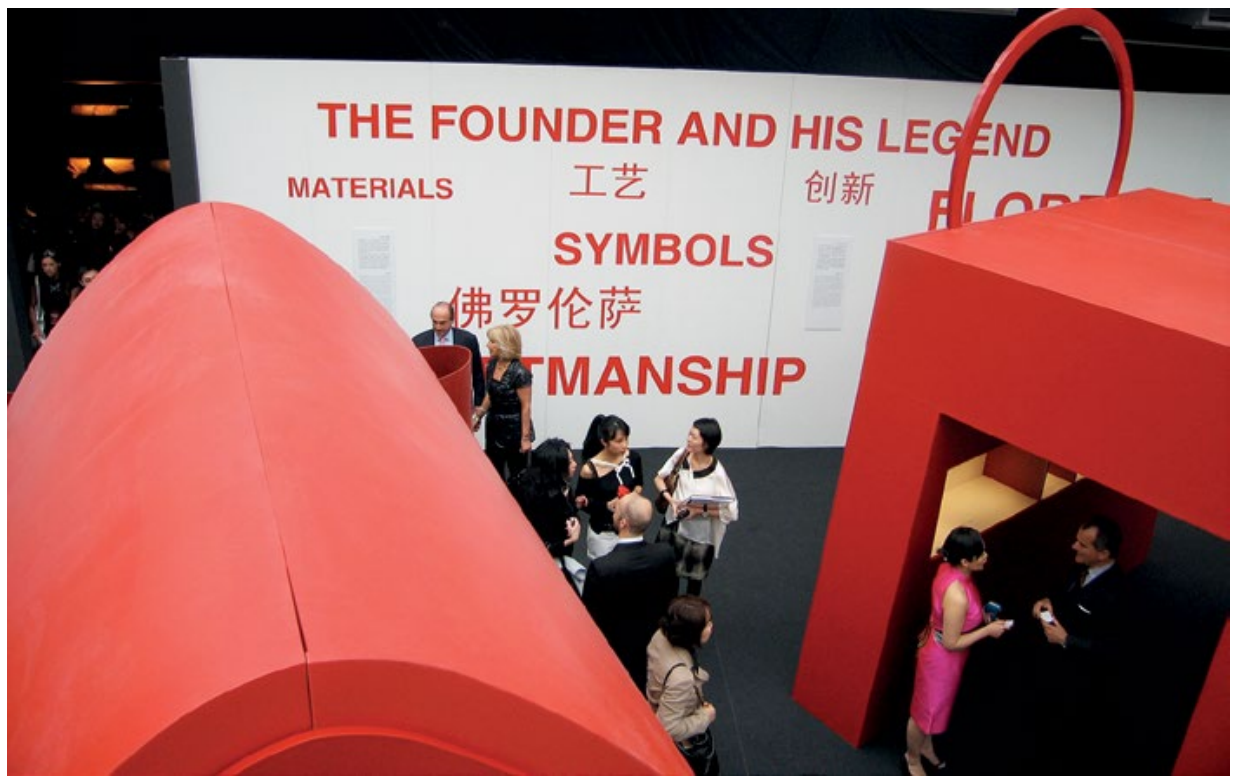

Figure 2. The Ferragamo party at Shanghai Moma

Photo: Simona Segre Reinach 2008

While Italian fashion is currently fragmented, there are individual projects that indicate unity (Frisa 2011). From a marketing point of view, the strength of Italian fashion lies in its capacity for constant change (Segre Reinach 2013), while maintaining a clear identity. As Chiara Colombi states:

The old claim-Think global, act local-is replaced then by-Think regional, Act local, Forget global-for which the Italian products, in order to move away from stereotypical interpretations, and to be understood in its value-laden complexity, must be supported by contextualising policies and strategies in the target markets in order to show respect for, and convey, one's identity of meanings and values. (2011: 58)

There are interesting examples of new brands that position themselves between artisan, craft and global trends. Their 'Italianness' is to be found more in the creative process than in the stereotypes of Italian glamour. From a theoretical point of view, however, the future scholars of Italian fashion, similarly with those actively involved in the sector, would profit from an approach that is both comparative and processual, questioning the ways in which Italian fashion differs from other fashion systems, if this is the case, and thus providing a cultural history of 'Made in Italy'. Italian 'good taste', which took shape in the years 
following 1950, was not the taste of an elite, as was the case for the French fashion which provided the taste of the urban bourgeoisie there (Bourdieu and Delsaut 1975). On the contrary, Italian fashion arose following a distancing of itself from the ritual of Parisian haute couture and, later, adopting aspects of a new popular culture that emerged after the decline of egalitarian ideologies of the 1970s; it is 'post-bourgeois' fashion.

\section{Conclusions}

A full examination of the sociological and anthropological issues concerning Italian fashion still needs to be completed. A museum of Italian fashion that presents a coherent narrative of the development of the style and industry should be established. It is not a coincidence that, despite the relevance of Italian fashion and the Italian fashion industry, its fashion schools are not recognised internationally. As Godart writes: 'with the notable exception of Italy-the best schools are located in a very limited number of countries, the United States, the United Kingdom, France, Belgium and Japan' (2012: 108-09). I am not in the position to judge whether Italian fashion schools are good enough or underestimated (and we should take also into account that books on Italian fashion written in Italian by Italian scholars are rarely translated into English) and, in the present globalised economy of the fashion industry, it could mean the same thing.

Italian fashion has been marked by a continuous transformation (Merlo 2003). I propose that the term metamorphosis usefully characterises the process of change that has been the hallmark of Italian fashion from the early 1950s, from the first catwalk shows in Florence, up to the present day in the globalised era. It is important to consider 'Made in Italy' - Italian fashion-as an open system, a structure that is sensitive to change and which responds to events with great vitality. It is not a closed formula that is aesthetically repeatable and encapsulated in a 'label of origin', as some consider, believing that by so doing they will enhance it, and instead impoverishing its more authentic value (Segre Reinach 2013). Its strength lies in its ability to evolve in time, to change while still remaining recognisable. Flexibility, considered a feature of Italian companies is also flexibility in knowing how to develop a concept and a positioning. If Italian fashion's ability to adapt to present-day conditions while preserving clear identity, that of Italian style, is to be taken as a possible heuristic device, most of the fashion theorists, and I include myself among them, Italian and non-Italian, shouldn't be afraid to face the reality of a system much celebrated but never really considered beyond its commercial success. To research Italian fashion implies unpacking the meaning of 'Made in Italy', in relation to Italian style and analysing the relationships between its cultural, economic and historical roots. 
Simona Segre Reinach is a cultural anthropologist and professor of fashion studies at Bologna University. She has written on fashion from a global perspective in Berg Encyclopedia of World Dress and Fashion (2010), The Fashion History Reader (2010), and published articles in Fashion Theory, Fashion Practice, Business and Economic History, and Critical Studies in Fashion and Beauty. She is author of four books in Italian: Mode in Italy (1999), La moda. Un'introduzione (2005, 2010), Orientalismi (2006), and Un mondo di mode (2011). She has done field work in China (2001-08) and contributed to a collaborative study on Sino-Italian joint ventures in the field of textile and fashion. She is also involved in Fashion Curation Studies and she curated the exhibition 80s-90s Facing Beauties. Italian Fashion and Japanese Fashion at a Glance (Museo della città di Rimini, 11 October - 8 December 2013). She sits on the editorial board of Fashion Theory, Dress Cultures Series by Tauris and The International Journal of Fashion Studies.

\section{References}

Blaszczyk, R.L. 2008, 'Rethinking fashion', in R.L. Blaszczyk (ed.), Producing Fashion, Philadelphia: University of Pennsylvania Press, pp. 1-18.

Bottoni, C., 2013, 'La ripresa del made in Italy', Milano Finanza.it, 5 February, viewed 8 August 2013, www.milanofinanza.it.

Bourdieu, P., and Delsaut, Y., 1975, 'Le couturier et sa griffe: contribution à une théorie de la magie', Actes de la recherche en science sociales, vol. 1, pp. 7-36.

Breward, C., 2004, Fashioning London, Oxford: Berg.

Bucci, A., Codeluppi, V. and Ferraresi, M., 2011, Il made in Italy, Milano: Carocci.

Caratozzolo, V.C., 2006, Irene Brin. Italian style in fashion, Venezia: Marsilio.

Colaiacomo, P., 2006, Fatto in Italia, Roma: Meltemi.

Colombi, C., 2011, 'Made in what Italia', ZoneModa Journal, pp. 57-59.

Crane, D. 2000, Fashion and its Social Agenda, University of Chicago Press.

Entwistle, J., 2009, The Aesthetic Economy of Fashion: Markets and Values in Clothing and Modelling (Dress, Body, Culture), Oxford, New York: Berg.

Foot, J., 2001, Milano dopo il miracolo, Milano: Feltrinelli.

Fortunati, L. and Danese, E., 2005, II made in Italy, Roma: Meltemi.

Frisa, M.L., 2011, Una nuova moda italiana, Venezia: Marsilio. 
Frisa, M.L. and Tonchi, S., 2014, Bellissima, exhibition catalogue, Milano: MAXXI Electa.

Fukai, A., Vinken, B., Frankel, S., Kurino, H. and Ince, C., 2010, Future Beauty. 30 Years of Japanese Fashion, Merrell, London, New York.

Geczy, A., 2013, Fashion and Orientalism, Bloomsbury.

Girard, R., 1979, Violence and the Sacred, Baltimore: Johns Hopkins University Press.

Godart, F., 2012, Unveiling Fashion, Palgrave Macmillan.

Kawamura, Y., 2004, The Japanese Revolution in Paris, Oxford: Berg.

Keane, M., 2013, Creative Industries in China. Art, Design and Media, Cambridge: Polity Press.

'La cultura della moda italiana/Made in Italy', 2011, Zonemoda Journal, February.

Lupano, M. and Vaccari, A. (eds), 2010, Fashion at the Time of Fascism, Bologna: Damiani.

Merlo, E., 2003, Moda italiana. Storia di un'industria dall'Ottocento a oggi, Venezia: Marsilio.

'Milan fashion landscape', Domus Moda, 2 October 1981.

Mulassano, A., 1979, The Who's Who of Italian Fashion, Firenze: Edizioni G. Spinelli \& C.

Muzzarelli, M.G., 2014. Breve storia della moda in Italia, Bologna: II Mulino.

Naldini, M., 2005, Uomini e moda, Dalai, Milano.

Paris, I., 2006, Oggetti cuciti, Milano: Franco Angeli.

Paulicelli, E., 2004, Fashion under Fascism. Beyond the Black Shirt, Oxford, New York: Berg.

Proni, G., 2011, 'Linee di ricerca per il made in Italy', Zonemoda Journal, vol. 2, pp. 60-67.

Sacchi, M.S., 2012, 'Il made in Italy tesse le alleanze di settore', Corriere Economia, 17 Sept.

Segre Reinach, S., 2014, 'The fashion revolution in Milan', in S. Stanfill (ed.), The Glamour of Italian Fashion, London: V\&A Publishers. 
- , 2013, 'Italian fashion. Metamorphosis of a cultural industry', in G.L. Maffei and K. Fallan (eds), Made in Italy. Rethinking a Century of Italian Design, Oxford: Berg, pp. 239-51.

-_, 2011, Un mondo di mode, Roma, Bari: Laterza.

- , 2010, 'La moda nella cultura italiana', in C. Petrini and U. Volli, Cibo, gioco, festa, moda, vol. 7, L.C. Sforza (ed.), La cultura italiana, pp. 603-61.

—-, 2006, 'Milan, the city of prêt à porter', in C. Breward and D. Gilbert (eds), Fashion's World Cities, Oxford: Berg, pp. 123-34.

Skov, L., 2011, 'Dreams of small nations in a polycentric fashion world', Fashion Theory, vol. 15, no. 2, pp. 137-56.

Steele, V., 2003, Italian Fashion, New Haven, London: Yale University Press.

Volonté, P., 2012. 'Social and cultural features of fashion design in Milan', Fashion Theory, vol. 16, no. 4, pp. 399-432.

White, N. 2000, Reconstructing Italian Fashion, Berg. 
This text is taken from Craft + Design Enquiry, Issue 7, 2015, edited by Kay Lawrence, published 2015 by ANU Press, The Australian National University, Canberra, Australia. 